\title{
Novel phenolic compound from Southern Ocean microalgae Chlorella sp. PR-1 and its antibacterial activity
}

\author{
Nuevo compuesto fenólico antibacteriano aislado de la microalga Chlorella sp. PR-1 del \\ océano sur
}

\section{Pratibha Gupta ${ }^{1,4}$, Aparna Banerjee ${ }^{2,3}$, Alexis Castillo³, Rajib Bandopadhyay,2,}

${ }^{1}$ Department of Bio-Engineering, Birla Institute of Technology, Mesra, Rachi-835215, Jharkhand, India.

${ }^{2}$ UGC-Center of Advanced study, Department of Botany, The University of Burdwan, Golapbag, Purba Bardhaman-713104, West Bengal, India.

${ }^{3}$ Centro de Investigación de Estudios Avanzados del Maule (CIEAM), Vicerrectoría de Investigación y Postgrado, Universidad Católica del Maule, Talca, Chile.

4Department of Biotechnology, Radha Govind University, Ramgarh, 829122 Jharkhand, India.

*E-mail: rajibindia@gmail.com

\section{ABSTRACT}

Marine microalgae has been attracting the researcher's attention for centuries. Development on microalgal research is majorly favoured by its medicinal, pharmaceutical or cosmeceutical properties. The advancement in the investigation related to microalgal products have been concentrated in the coastal zones because of the greater supply of raw material. The Southern Ocean, highly productive and relatively poorly studied ecosystem, constitutes approximately $10 \%$ of the global volume of the oceans. In this study, marine microalgae Chlorella sp. PR-1 was isolated from the Southern Ocean (Indian Sector) for the identification of bioactive antibacterial compounds. The antimicrobial activity of this microalgal extracts was evaluated against three gram positive (Staphylococcus aureus, Bacillus licheniformis, and Bacillus subtilis) and three gram negative bacteria (Pseudomonas aeruginosa, Salmonella typhimurium, and Escherichia coli). The extract showing antibacterial activity was further purified by thin layer and column chromatography. The antimicrobial activity was again evaluated and confirmed with the purified fraction against the same bacteria. The identification of the functional groups in the purified fraction was performed by infrared spectroscopic analysis. Based on gas chromatographic and mass spectroscopic analysis, the principle bioactive compound was proved to be 2,4-bis (1,1-dimethylethyl)- phenol. Thus, the bioactive compound isolated from marine microalga of Southern Ocean origin may be a novel alternative source of antibacterials in the future.

Keywords: antibacterial activity, microalgae, phenolic compound, Southern Ocean.

\section{RESUMEN}

Las microalgas marinas han atraído la atención de los investigadores durante siglos. El desarrollo de la investigación de las microalgas se ve favorecido principalmente debido a sus propiedades medicinales, farmacéuticas y cosméticas. El avance de las investigaciones relacionadas con productos microalgales se ha concentrado en las zonas costeras debido a la mayor oferta de materias primas. El Océano Sur es un ecosistema extremo altamente productivo y relativamente poco estudiado, constituye aproximadamente el $10 \%$ del volumen global de los océanos. En este estudio, la microalga marina Chlorella sp. PR-1 fue aislada desde el Océano Sur (sector Indico) para la identificación de compuestos bioactivos antibacterianos. La actividad antimicrobiana de los extractos microalgales fue evaluada contra tres especies bacterianas gram 
positivas (Staphylococcus aureus, Bacillus licheniformis y Bacillus subtilis) y tres gram negativas (Pseudomonas aeruginosa, Salmonella typhimurium y Escherichia coli). Los extractos que mostraron actividad antibacteriana fueron purificados mediante cromatografía de capa fina. La actividad antibacteriana de las fracciones purificadas fue evaluada nuevamente y confirmada contra las mismas bacterias. En las fracciones purificadas, la identificación de los grupos funcionales fue realizada mediante análisis espectroscópico infrarrojo. Basado en los análisis cromatográficos y de espectroscopia de masa se demostró que el principal compuesto bioactivo fue 2,4-bis (1,1-dimetiletil)-fenol. Por lo tanto, el compuesto bioactivo aislado de microalgas marinas del Océano Austral puede ser una nueva fuente alternativa de antibacterianos en el futuro.

Palabras clave: actividad antibacteriana, compuestos fenólicos, microalga, Océano Sur.

\section{INTRODUCTION}

Now a days a major threat to public health is emergence of drug resistance. In fact, chronic break out of multidrug resistance is of more concern than any other health issues (Tanwar et al. 2014, Ventola 2015, Ferri et al. 2017, Tayler et al. 2019). Since the last 90 years of antibiotic discovery, major throwback is observed in the present time where literally no drug can be applied to certain diseases causing decrease in life expectancy. Thus, finding alternative to antibiotics is a major challenge nowadays (Allen et al. 2014; Czaplewski et al. 2016). Whereas terrestrial plants or microbes have been studied a lot for discovery of bioactive compounds, relatively less are explored from extreme environments like ocean. Ocean offers infinite biodiversity potential most of which are still uncharacterized and may eventually develop into novel therapeutics (Newman \& Cragg 2012, Gupta et al. 2015, Banerjee et al. 2019). Southern Ocean (Indian sector) harbors affluent microbial diversity that are promising source of unique bioactive compounds (Banerjee et al. 2019, Sengupta et al. 2019). Hence, they are of great scientific interest and make Southern Ocean as incipient biomedical resource (Chin et al. 2006, Harvey 2008, Banerjee et al. 2019).

Marine microalgae survive at extreme environments including high pressure, salinity, or temperature (Paerl et al. 2000). To adapt to these extreme conditions, microalgae produce variety of secondary metabolites with effective biological potentials like anticancerous, antibacterial, antiprotozoal, anticoagulant, antituberculosis, antimalarial, anti-inflammatory or antifungal activity (Montaser \& Luesch 2011, Gerwick \& Moore 2012, Gupta et al. 2014). Apart from these, marine microalgae are also referred as potential source of biofuels or in cosmeceuticals (Quinn et al. 2008, Bhatnagar \& Kim 2010, Mayer et al. 2010, Penesyan et al. 2010, Gomma et al. 2015, Mourelle et al. 2017, Maeda et al.
2018). Especially in recent times, different species of Chlorella has become an important source for biodiesel production (Cheirsilp et al. 2012, Kirrolia et al. 2014, Zhang et al. 2014, Mathimani et al. 2017, Mathimani et al. 2018, Chi et al. 2019), wastewater treatment and heavy metal removal (Kumar \& Goyal 2010, Das et al. 2018, Amin \& Chetpattananondh 2019). Our present study involves disc diffusion method for identification of the antibacterial compounds from Southern Ocean (Indian sector) origin marine microalgae Chlorella sp. PR-1 against some pathogenic and non-pathogenic bacteria. The extraction of the bioactive compounds has been done according to the standard methods followed by its identification using typical thin layer chromatography (TLC), infrared spectroscopy (FTIR) and gas chromatographic technique coupled with mass spectrometry (GC-MS).

\section{MATERIALS AND METHODS}

Isolation of Chlorella sp. Pr1 and extract preparation

Marine microalgae Chlorella sp. PR-1 (MN850879) was reported to be isolated from water sample $\left(44^{\circ} \mathrm{S} ; 48^{\circ} \mathrm{E}\right)$ collected from Southern Ocean (Indian sector) expedition 2011 (Gupta et al. 2014). Map of the study site prepared using Ocean Data View software is represented in Fig. 1. The hydrographic characteristics of the sampling station is noted in Table 1.

Sterilized natural seawater enriched with $F / 2$ media was used to culture Chlorella sp. PR-1 (Guillard 1975). It was incubated at $56 \mu \mathrm{mol} \mathrm{m} \mathrm{m}^{-2} \mathrm{~s}^{-1}$ luminous irradiance, light/ dark conditions of $16: 8 \mathrm{~h}$ and gentle agitation at $20^{\circ} \mathrm{C}$. The batch culture was harvested at late log phase after 8 days of incubation by centrifugation at $3000 \mathrm{rpm}$ for $5 \mathrm{~min}$ and further oven drying at $45^{\circ} \mathrm{C}$ for $48 \mathrm{~h}$. All the solvent used for extraction, isolation and purification were of HPLC grade. 
Dried algal biomass of $50 \mathrm{mg}$ was soaked in $50 \mathrm{ml}$ methanol (99.9\%) and was kept for two days continuous shaking at room temperature, which was then filtered in whatman filter paper. The methanol extract was further subjected for liquidliquid separation according to modified Kupchan \& Tsou (1973) protocol. After the separation, five different extracts viz. n-hexane, carbon tetrachloride $\left(\mathrm{CCl}_{4}\right)$, chloroform, ethyl acetate, and methanol fractions were collected and used for the antibacterial assay.

\section{Antibacterial STUdies}

Antibacterial activity of all the Chlorella sp. PR-1 filtrates was performed by Kirby Bauer disc diffusion method (Bauer et al.
1966) against gram-negative Pseudomonas aeruginosa (NCIM 2036), Salmonella typhimurium (NCIM 2501) and Escherichia coli (NCIM 2832) along with gram-positive Staphylococcus aureus (NCIM 2122), Bacillus licheniformis (NCIM 2042) and Bacillus subtilis (NCIM 2193). Sterile cotton swabs were used to spread freshly grown test bacteria on Mueller Hinton $(\mathrm{MH})$ agar (Himedia $\left.{ }^{\circledR}\right)$ plates and were left for some times to allow complete absorption of the inoculum. The disc loaded with $15 \mu \mathrm{l}$ of each extracts was placed on each plates and then kept for incubation at $37{ }^{\circ} \mathrm{C}$ for $24 \mathrm{~h}$. Clear zone was observed around the disc, which denoted the presence of antibacterial compounds in the extracts. Zone of inhibitions were measured in millimetres ( $\mathrm{mm})$.

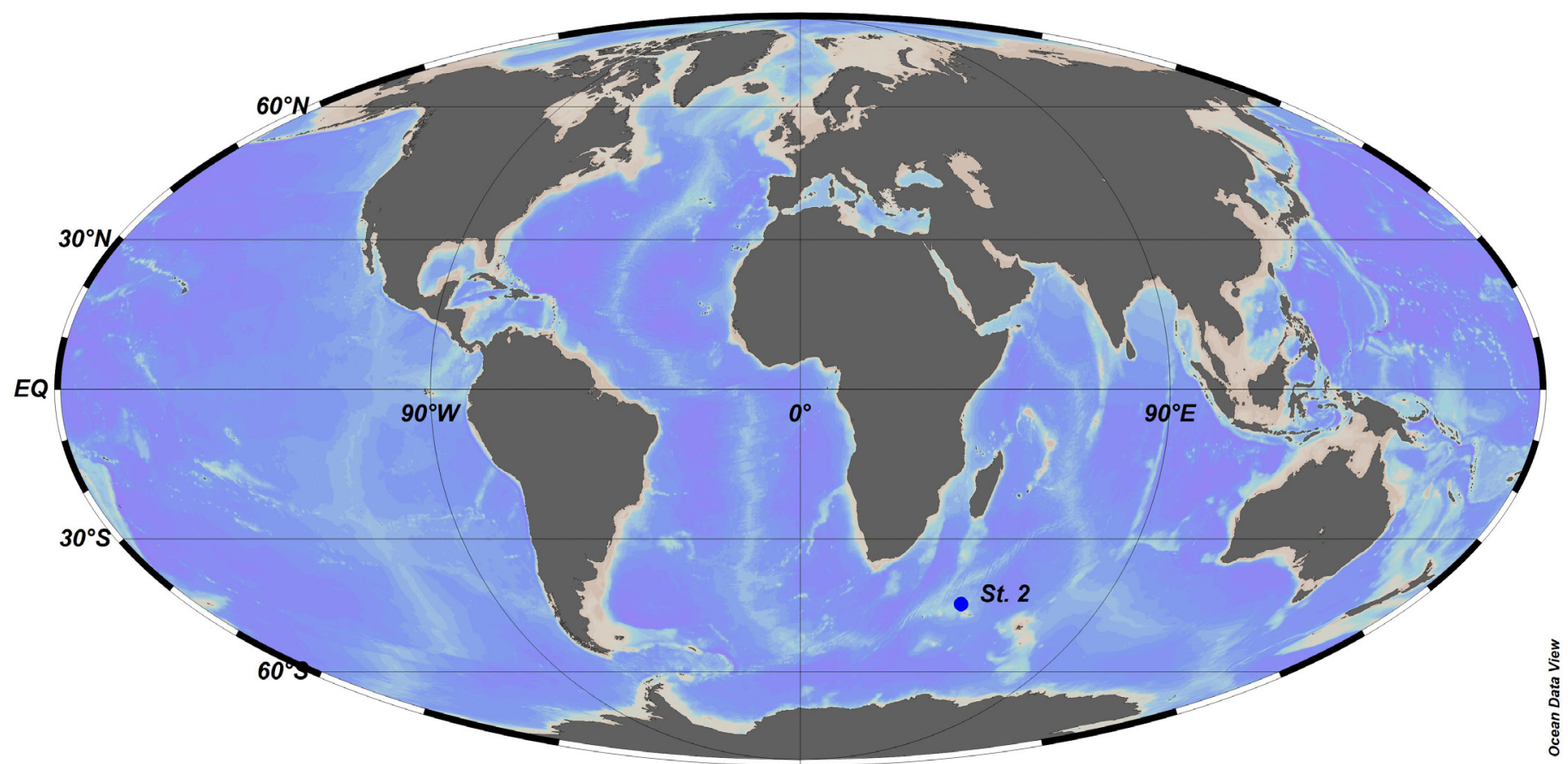

Figure 1. Map of the study zone representing the point of water sample collection at station 2 of the Southern Ocean (Sector India). The map was generated using Ocean Data View software (Schlitzer 2010). / Mapa de la zona de estudio que indica el punto de la recolección de muestras de agua en la estación 2 del Océano Sur (Sector Indico). Mapa generado mediante software Ocean Data View (Schlitzer 2010).

TABLE 1. Hydrographic Characteristics of the sampling station in the Southern Ocean (Indian sector). / Características hidrográficas de la estación de muestreo en el Océano Sur (Sector Indico).

\begin{tabular}{cccccccc}
\hline $\begin{array}{c}\text { Station } \\
\text { name }\end{array}$ & $\begin{array}{c}\text { Temperature } \\
\left({ }^{\circ} \mathrm{C}\right)\end{array}$ & $\begin{array}{c}\text { Latitude } \\
\left({ }^{\circ} \mathrm{S}\right)\end{array}$ & $\begin{array}{c}\text { Longitude } \\
\left({ }^{\circ} \mathrm{E}\right)\end{array}$ & $\begin{array}{c}\text { Depth of } \\
\text { sampling }(\mathrm{m})\end{array}$ & $\begin{array}{c}\text { Depth } \\
\left(\mathrm{m} . \mathrm{b} . \mathrm{s} . \mathrm{I}^{*}\right)\end{array}$ & $\begin{array}{c}\text { Sea surface temperature/ } \\
\text { SST }\left({ }^{\circ} \mathrm{C}\right)\end{array}$ & $\begin{array}{c}\text { Wind speed } \\
(\text { Knotts })\end{array}$ \\
\hline $\begin{array}{c}\text { Station } \\
2\end{array}$ & 12 & 44 & 48 & 90 & 5225 & 20.5 & $\begin{array}{c}\text { Wind } \\
\text { direction }\end{array}$ \\
\hline
\end{tabular}

*meters below sea level 


\section{EXTRACTION AND IDENTIFICATION OF BIOACTIVE COMPOUND}

$\mathrm{CCl}_{4}$ fraction of Chlorella sp. PR-1 showing the best antibacterial activity was further assayed for detail evaluation on the presence of antibacterial compound on TLC. The active fraction was loaded on silica plate (Silica gel 60; Merck, India) with ethyl acetate/ hexane (3:2) solution. Thick single band with antibacterial action was identified under UV-transillumination at $366 \mathrm{~nm}$. The elution was subjected for GC-MS (Agilent Technologies, USA) having HP 5MS + $10 \mathrm{~m}$ Duraguard capillary column $(30 \mathrm{~m} \times 0.25 \mathrm{~mm} \times 0.25 \mu \mathrm{m})$ attached to MSD Triple axis detector, operating in electron impact mode at $70 \mathrm{eV}$. Helium was used as carrier gas at constant flow rate of $1 \mathrm{ml} / \mathrm{min}$, ion source temperature 230 ${ }^{\circ} \mathrm{C}$, quadrupole temperature $150{ }^{\circ} \mathrm{C}$, auxiliary temperature $280{ }^{\circ} \mathrm{C}$ and sample injection volume $1 \mu \mathrm{l}$. As the GC-MS data revealed total 23 compounds, $\mathrm{CCl}_{4}$ extract was further subjected for column chromatography to fractionate all 23 compounds. The column was packed with silica (Silica gel 60-120; Merck, India). EtOAc: Hexane solvent was used in a gradient manner with increasing polarity. All the column chromatography fractions were collected and antibacterial assay was again performed against $S$. typhimurium that showed the best bioactivity. Fraction showing positive activity was further subjected to FTIR analysis (IR-Prestige 21, Shimadzu Corporation, Japan) between $400-4000 \mathrm{~cm}^{-1}$ by the $\mathrm{KBr}$ pellet technique, followed by high pressure liquid chromatography (HPLC) with Symmetry C18 $5 \mu \mathrm{m} 4.6 \times 150 \mathrm{~mm}$ column (Waters, Ireland). The mobile phase consisted of water with $0.1 \%$ acetic acid (solvent $A$ ) and acetonitrile (solvent $B$ ). The different gradients of solvent $B$ were $0-4$ min gradient with $4 \%$ solvent B for $4-6$ min, $17 \%$ for 6-10 min and $30 \%$ solvent
$B$ and $10-15 \min 4 \%$ solvent $B$. The flow rate was $1 \mathrm{ml} / \mathrm{min}$, injection volume $20 \mu \mathrm{l}$ and the monitoring wavelength of 280 $\mathrm{nm}$. After that, the fraction was subjected to GC-MS (GCMSQP2010 Plus, USA) with Rtx- $5 \mathrm{Ms}(30 \mathrm{~m} \times 0.25 \mathrm{~mm}$ ID $\times 0.25 \mu \mathrm{m}$ df) column attached through MSD Triple axis detector. The operating characteristics was as earlier described with $1 \mu l$ injection volume. Identification of the compound was based on the comparison of their retention time with the compound database of WILEY8.LIB library.

\section{RESULTS}

\section{ANTIBACTERIAL STUDIES}

All the fractions of the marine isolate Chlorella sp. PR-1 were tested against both the sets of gram positive and gram negative bacteria $S$. typhimurium, S. aureus, E. coli, P. aeruginosa, $B$. subtilis and $B$. licheniformis. Among these, $\mathrm{CCl}_{4}$ fraction of Chlorella sp. PR-1 demonstrated positive biocidal activity against $S$. typhimurium with $10 \pm 0.5 \mathrm{~mm}$ zone of inhibition; whereas rest of the hexane, ethyl acetate and methanol fractions did not exhibited any significant activities against all the bacteria (Fig. 2).

\section{STRUCTURAL IDENTIFICATION OF THE BIOACTIVE COMPOUND} $\mathrm{CCl}_{4}$ fraction of Chlorella sp. PR-1 showing antibacterial activity against $S$. typhimurium was subjected to TLC and the specific band was observed at $R_{f}$ value of 0.42 . GC-MS analysis revealed 23 different natural compounds present in the extract. These compounds were mainly comprised of hexachloroethane (18.42\%), followed by isophthalic acid and heptyl 2-methyl prop-2-en-1-yl ester (16.25\%). Rest

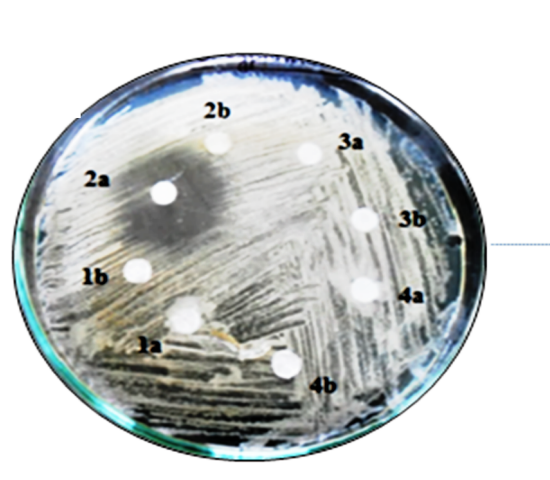

Chlorella sp. PR-1 CCl4 extract

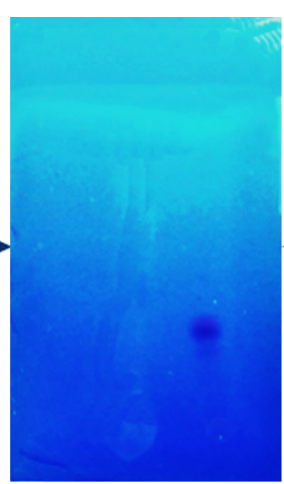

TLC

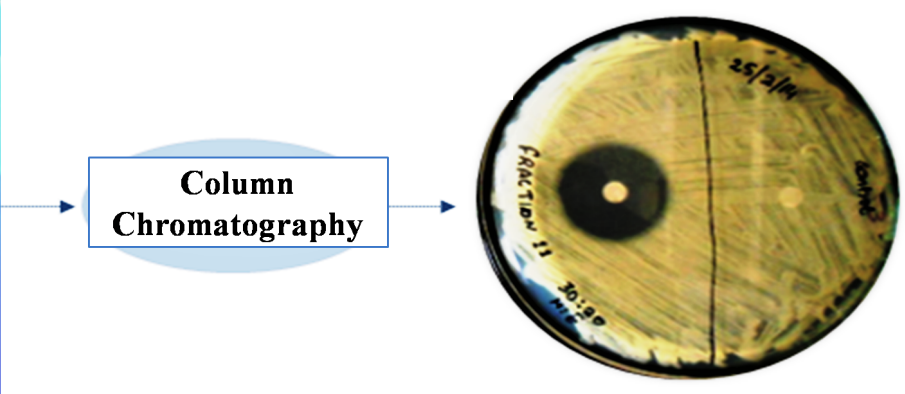

Purified fraction

FIGURE 2. Antibacterial activity of Chlorella sp. PR-1 against Salmonella typhimurium confirmed using TLC and fraction purified through column chromatography. Purified fraction confirms the inhibition to S. typhimurium. / Actividad antibacteriana de Chlorella sp. PR-1 contra Salmonella typhimurium confirmada usando TLC y fracción purificada mediante columna cromatográfica. Fracción purificada confirma la inhibición de S. typhimurium. 
of the compounds were less than $10 \%$ which constituted Phenol 2,2-methylenebis [6-(1,1-dimethylethyl)-4-methyl-] (9.25\%), [2,4-bis (1,1-dimethylethyl)- phenol] (8.65\%), etc. Through column chromatography, it was observed that $11^{\text {th }}$ fraction eluted with ethyl acetate: hexane (30:20) exhibited antibacterial activity against $S$. typhimurium. HPLC analysis of carbon tetrachloride fraction shows single peak with 2.510 retention time. Area and height of the peak were 188768 and 34941 respectively (Fig. 3). For identification of the functional groups, FTIR spectroscopy was performed at different wavelength. The bands 2924.09 and 2826.36 were assigned to $\mathrm{C}-\mathrm{H}$ stretching vibration, while 1743.65 was of cyclopentanone. The IR absorptions at 1550.77 and 1377.17

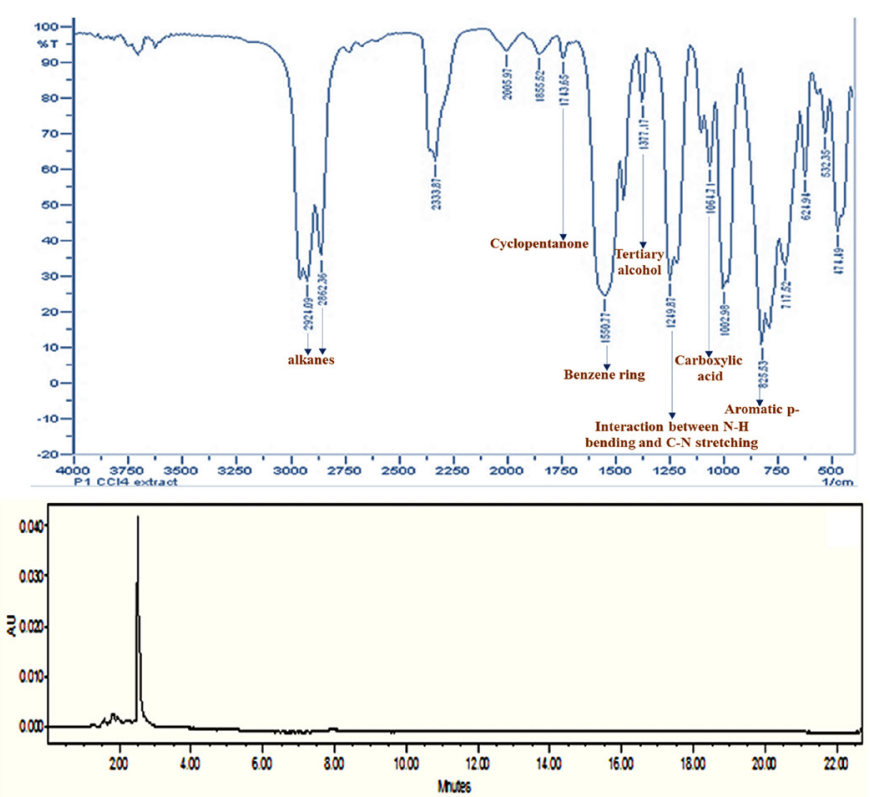

FIGURE 3. Structural identification of antibacterial compounds produced by Chlorella sp. PR-1 through FTIR and GC analysis. / Identificación estructural del compuesto antibacteriano producido por Chlorella sp. PR-1 mediante análisis de FTIR-GC.

\section{DISCUSSION}

Microalgal biomass is widely studied as a promising source to several industry-based applications; like biofuel production, bioremediation, carotenoids, polyunsaturated fatty acids, phycobiliproteins and more (Syed et al. 2015; Liang et al. 2019, De Souza et al. 2018). The ability of microalgae to grow were also indicative of benzene ring and tertiary alcohol respectively. GC chromatogram showed 3 peaks; out of which one peak ( $\mathrm{Rt}=17.954$ ) belonged to 2,4-bis (1,1-dimethylethyl)phenol. GC-MS of the crude extract showing 23 peaks, also contained one 2,4-bis (1,1-dimethylethyl)- phenol peak on it (Fig. 4). So, 2,4-bis (1,1-dimethylethyl)- phenol was the actual compound responsible for biocidal property. The structure of the compound was identified based on the comparison of its retention time with the compound database present in NIST library. The rest two peaks belonging to 1-Tetradecene and Pentadecane were probably due to the column impurities that came along the compound.

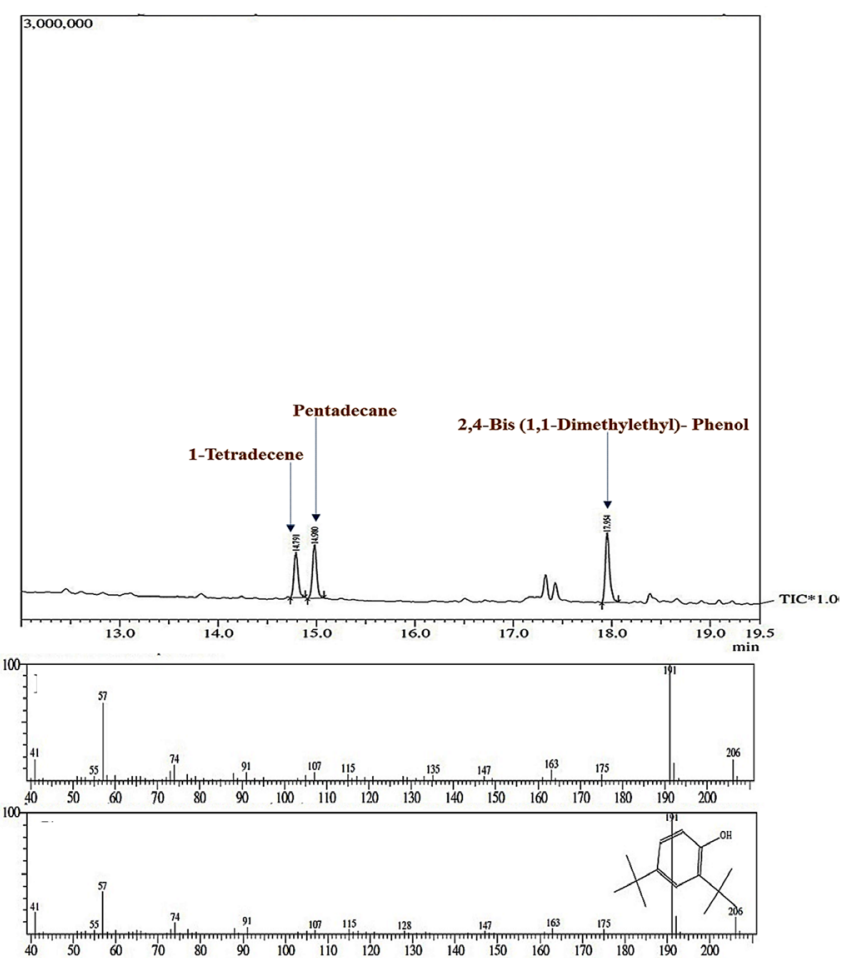

FIGURE 4. GC-MS analysis showing 2,4-bis (1,1-dimethylethyl)phenol as the primary bioactive compound for antibacterial activity against $S$. typhimurium. / Análisis de GC-MS que muestra el 2,4-bis (1,1-dimetiletil)-fenol como compuesto bioactivo primario para la actividad antibacteriana contra $S$. typhimurium.

in otherwise inhospitable conditions, as well as their ability to metabolic adaptation under stress conditions, makes them attractive as raw material for large-scale cultivation and industrial applications (Katiyar et al. 2017). Marine environments supports diverse group of microorganisms and among them microalgae are identified to be one of the key members because of the biotechnological interests (Falaise 
et al. 2016). In the present study, microalgae Chlorella sp. PR1 was isolated as a part of Southern Ocean (Indian sector) expedition 2011. Because of relatively fewer reports on biology of Southern Ocean microorganisms, this habitat is an example of one of the least explored ecosystem on earth with immense future possibilities (Banerjee et al. 2019). In this study, $\mathrm{CCl}_{4}$ fraction of the marine microalgae Chlorella sp. PR1 displayed promising antibacterial property against the pathogen S. typhimurium. In 1944, the pioneer work of Pratt demonstrated the antimicrobial activity of green alga Chlorella against several gram negative and gram positive bacteria (Pratt et al. 1944). A similar study was also reported by Asthana et al. (2009) where $0.22 \mu \mathrm{g}$ methanol extract of Antarctic cyanobacterium Nostoc CCC537 inhibited S. typhimurium with $10 \mathrm{~mm}$ zone of inhibition. After that, several bioactive compounds were isolated from microalgae that are available in market. In another report, methanol and chloroform (1:1) extract of marine algae Dunaliella salina have appreciable antimicrobial activity against a group of both gram positive and gram negative pathogenic bacteria (Krishnakumar et al. 2013). The carotenoid pigment and chlorophyll of green algae Chlorococcum humicola showed the activity of inhibiting the growth of virulent bacteria and pathogenic fungi (Bhagavathy et al. 2011). Bioactive fatty acids from Haematococcus pluvialisa and Scenedesmus obliquus were also reported to have antibacterial property against pathogenic bacteria (RodríguezMeizoso et al. 2010; Santoyo et al. 2009; Guedes et al. 2011). Compared to all these reports, in the present study $15 \mu \mathrm{g}$ $\mathrm{CCl}_{4}$ extract of Chlorella sp. PR-1 inhibited the growth of $\mathrm{S}$. typhimurium with $10 \pm 0.5 \mathrm{~mm}$ zone of inhibition. The bioactive antibacterial compound responsible for the inhibition of S. typhimurium was further characterized through TLC, column chromatography, FTIR, HPLC and GC-MS. The FTIR spectrum indicated the presence of $\mathrm{C}-\mathrm{H}$ stretching vibration, cyclopentanone, benzene ring and tertiary alcohols that are commonly found to have antimicrobial properties against both gram positive and gram negative bacteria (Cowan 1999, Barnos et al. 2007, Kostic et al. 2012, Wang et al. 2012, Zhang et al. 2012, You et al. 2014). In our preliminary study report, it has been characterized that 2,4-Bis (1,1-dimethylethyl)phenol isolated from marine microalgae Chlorella sp. PR-1 is the biocide that showed promising antibacterial action to $S$. typhimurium. The likely mechanism by which the growth of $S$. typhimurium was inhibited is phenol-induced pyroptosis and apoptosis involving flexible deployment of caspases (Kinsella \& Stallings 2020). S. typhimurium is susceptible to $\mathrm{OH}$ group of the phenols that act as a proton exchanger reducing the $\mathrm{pH}$ gradient across the cell membrane and thus leading to cell death. Phenolic compounds also interact with some crucial enzymes responsible for the production of the precursors of bacterial cell membrane or enzymes involved in fatty acid biosynthesis (Gyawali \& Ibrahim 2014). Marine microalgal compounds is also newly revealed to inhibit enterobacteria, S. typhimurium (Machado et al. 2020). Phenols constitute one the largest group of secondary metabolites isolated from microalgae. In vitro antibacterial activity of the microalgae against Bacillus spp., Salmonella spp. and from Staphylococcus aureus were linked with phenolic compounds (Pina-Perez et al. 2017). Further, nuclear magnetic resonance (NMR) analysis may elucidate the detail structural features of the bioactive compound that may be used as alternative antimicrobials in future. Thus, the present study discloses a novel, marine microalgae-origin biocide, which may open new trends in biopharmaceutical industries.

\section{ACKNOWLEDGEMENT}

The authors are thankful for Expedition support to MoES, New Delhi and NCAOR, Goa (No. MoES/NCAOR/SOS/1/2007PC-I; dated Jan 04, 2011). They are also thankful to Government of Jharkhand, Department of Agriculture for providing infrastructure development facilities (5/B.K.V/ Misc/12/2001) and Department of Botany, The University of Burdwan for laboratory facilities.

\section{REFERENCES}

Allen, H.K., Trachsel, J., Looft, T., Casey, T.A. 2014. Finding alternatives to antibiotics. Annals of the New York Academy of Sciences 1323(1): 91-100.

Amin, M., Chetpattananondh, P. 2019. Biochar from extracted marine Chlorella sp. residue for high efficiency adsorption with ultrasonication to remove $\mathrm{Cr}(\mathrm{VI}), \mathrm{Zn}$ (II) and Ni (II). Bioresource Technology 289: 121578.

Asthana, R.K., Deepali, Tripathi, M.K., Srivastava, A., Singh, A.P., Singh, S.P., Nath, G., Srivastava, R., Srivastava, B. 2009. Isolation and identification of a new antibacterial entity from the Antarctic cyanobacterium Nostoc CCC 537. Journal of Applied Phycology 21(1): 81-88.

Banerjee, A., Gupta, P., Nigam, V., Bandopadhyay, R. 2019. Bacterial exopolysaccharides from extreme marine habitat of Southern Ocean: Production and partial characterization. Gayana 83(2): 126-134.

Barnos, L., Calhelha, R.C., Vaz, J.A., Ferreira, C.F.R., Baptista, P., Estevinho, L.M. 2007. Antimicrobial activity and bioactive compounds of Portuguese wild edible mushrooms methanolic extracts. European Food Research Technology 225(2): 151-156. 
Bauer, A.W., Kirby, W.M., Sherris, J.C., Turck, M. 1966. Antibiotic susceptibility testing by a standardized single disk method. American Journal of Clinical Pathology 45: 493-496.

Bhagavathy, S., Sumathi, P., Jancy Sherene Bell, I. 2011. Green algae Chlorococcum humicola - a new source of bioactive compounds with antimicrobial activity. Asian Pacific Journal of Tropical Biomedicine 1(1): S1-S7.

Bhatnagar, I., Kim, S. 2010. Marine antitumor drugs: Status, shortfalls and strategies. Marine Drugs 8(10): 2702-2720.

Cheirsilp, B., Kitcha, S., Torpee, S. 2012. Co-culture of an oleaginous yeast Rhodotorula glutinis and a microalga Chlorella vulgaris for biomass and lipid production using pure and crude glycerol as a sole carbon source. Annals of Microbiology 62(3): 987-993.

Chi, N.T., Duc, P.A., Mathimani, T., Pugazhendhi, A. 2019. Evaluating the potential of green alga Chlorella sp. for high biomass and lipid production in biodiesel viewpoint. Biocatalysis and agricultural biotechnology 17: 184-188.

Chin, Y.W., Balunas, M.J., Chai, H.B., Kinghorn, A.D. 2006. Drug discovery from natural sources. The AAPS Journal 8(2): E239-253.

Cowan, M.M. 1999. Plant products as antimicrobial agents. Clinical Microbiology Reviews 12(4): 564-582.

Czaplewski, L., Bax, R., Clokie, M., Dawson, M., Fairhead, H., Fischetti, V.A., Foster, S., Gilmore, B.F., Hancock, R.E., Harper, D., Henderson, I.R. 2016. Alternatives to antibiotics-a pipeline portfolio review. The Lancet Infectious Diseases 16(2): 239-251.

Das, C., Ramaiah, N., Pereira, E., Naseera, K. 2018. Efficient bioremediation of tannery wastewater by monostrains and consortium of marine Chlorella sp. and Phormidium sp. International Journal of Phytoremediation 20(3): 284292.

De Souza, M.P., Hoeltz, M., Gressler, P.D., Benítez, L.B., Schneider, R.C. 2018. Potential of microalgal bioproducts: general perspectives and main challenges. Waste and Biomass Valorization 2018: 1-8.

Falaise, C., Cyrille, F., Marie-Agnes, T., Morga, B., Haure. J., Tremblay, R., Turcotte, F., Pasetto, P., Gastineau, R., Hardivillier, Y., Leignel, V., Jean-Luc, M. 2016. Antibacterial compounds from eukaryotic microalgae against human pathogens and diseases in aquaculture. Marine Drugs 14: 159.

Ferri, M., Ranucci, E., Romagnoli, P., Giaccone, V. 2017. Antimicrobial resistance: a global emerging threat to public health systems. Critical Reviews in Food Science and Nutrition 57(13): 2857-2876.

Gerwick, W.H., Moore, B.S. 2012. Lessons from the past and charting the future of marine natural products drug discovery and chemical biology. Chemistry and Biology
19(1): 85-98.

Gomma, A.E., Lee, S.K., Sun, S.M., Yang, S.H., Chung, G. 2015. Improvement in Oil Production by Increasing MalonylCoA and Glycerol-3-Phosphate Pools in Scenedesmus quadricauda. Indian Journal of Microbiology 55(4): 447455.

Guedes, A.C., Barbosa, C.R., Amaro, H.M., Pereira, C.I., Malcata, F.X. 2011. Microalgal and cyanobacterial cell extracts for use as natural antibacterial additives against food pathogens. International Journal of Food Science \& Technology 46: 862-870.

Gupta, P., Balaji, R., Parani, M., Chandra, T.S., Shukla, P., Kumar, A., Bandopadhyay, R. 2015a. Phylogenetic analysis and biological characteristic test of marine bacteria isolated from Southern Ocean (Indian sector) water. Acta Oceanologica Sinica 34(8): 73-82.

Gupta, P., Kumar, H., Bandopadhyay, R. 2015b. Distribution pattern of bacteria in the two geographic poles and Southern Ocean from the reported $16 \mathrm{~S}$ rDNA sequences. Current Science 108(10): 1926-1930.

Gupta, P., Sinha, D., Bandopadhyay, R. 2014. Isolation and screening of marine microalgae Chlorella sp. PR-1 for anticancer activity. International Journal of Pharmacy and Pharmaceutical Sciences 6(10): 517-519.

Gyawali, R., Ibrahim, S.A. 2014. Natural products as antimicrobial agents. Food Control 46: 412-429.

Harvey, A.L. 2008. Natural products in drug discovery. Drug Discovery Today 13(19-20): 894-901.

Katiyar, R., Gurjar, B.R., Biswas, S., Pruthi, V., Kumar, N., Kumar, P. 2017. Microalgae: an emerging source of energy based bio-products and a solution for environmental issues. Renewable and Sustainable Energy Reviews 2: 10831093.

Kinsella, R.L., Stallings, C.L. 2020. A Flexible and Deadly Way to Control Salmonella Infection. Immunity 53(3): 471-473.

Kirrolia, A., Bishnoi, N.R., Singh, R. 2014. Response surface methodology as a decision-making tool for optimization of culture conditions of green microalgae Chlorella spp. for biodiesel production. Annals of Microbiology 64(3): 1133-1147.

Kostic, D.A., Velickovic, J.M., Mitic, S.S., Mitic, M.N., Randelovic, S.S. 2012. Phenolic content, and antioxidant and antimicrobial activities of Crataegus oxyacantha L. (Rosaceae) fruit extract from Southeast Serbia. Tropical Journal of Pharmaceutical Research 11(1): 117-124.

Krishnakumar, S., Dooslin Mercy Bai, V., Alexis Rajan, R. 2013. Evaluation of Bioactive Metaboloites from Halophilic microalgae Dunaliella salina by GC-MS analysis. International Journal of Pharmacy and Pharmaceutical Sciences 5(4): 296-303. 
Kumar, R., Goyal, D. 2010. Waste water treatment and metal $\left(\mathrm{Pb}^{2+}, \mathrm{Zn}^{2+}\right)$ removal by microalgal based stabilization pond system. Indian Journal of Microbiology 50: 34-40.

Kupchan, S.M., Tsou, G. 1973. Tumor inhibitors. A new antileukemic simaroubolide from Brucea antidysenterica. Journal of Organic Chemistry 38: 178-179.

Liang, M.H., Wang, L., Wang, Q., Zhu, J., Jiang, J.G. 2019. Highvalue bioproducts from microalgae: strategies and progress. Critical Reviews in Food Science and Nutrition 59(15): 2423-2441.

Machado, T.W., Rodrigues, J.M., Moro, T.R., Duarte, M.E., Noseda, M.D. 2020. Marine Microalgae Biomolecules and Their Adhesion Capacity to Salmonella enterica sv. Typhimurium. Applied Sciences 10(7): 2239.

Maeda, Y., Yoshino, T., Matsunaga, T., Matsumoto, M., Tanaka, T. 2018. Marine microalgae for production of biofuels and chemicals. Current Opinion in Biotechnology 50: 111-120.

Mathimani, T., Kumar, T.S., Chandrasekar, M., Uma, L., Prabaharan, D. 2017. Assessment of fuel properties, engine performance and emission characteristics of outdoor grown marine Chlorella vulgaris BDUG 91771 biodiesel. Renewable Energy 105: 637-646.

Mathimani, T., Uma, L., Prabaharan, D. 2018. Formulation of lowcost seawater medium for high cell density and high lipid content of Chlorella vulgaris BDUG 91771 using central composite design in biodiesel perspective. Journal of Cleaner Production 198: 575-586.

Mayer, A.M., Glaser, K.B., Cuevas, C., Jacobs, R.S., Kem, W., Little, R.D., Mcintosh, J.M., Newman, D.J., Potts, B.C., Shuster, D.E. 2010. The odyssey of marine pharmaceuticals: a current pipeline perspective. Trends in Pharmacological Science 31(6): 255-265.

Montaser, R., Luesch, H. 2011. Marine natural products: a new wave of drugs? Future Medicinal Chemistry 3(12): 14751489.

Mourelle, M.L., Gómez, C.P., Legido, J.L. 2017. The potential use of marine microalgae and cyanobacteria in cosmetics and thalassotherapy. Cosmetics 4(4): 46.

Newman, D.J., Cragg, G.M. 2012. Natural products as sources of new drugs over the 30 years from 1981 to 2010. Journal of Natural Products 75(3): 311-335.

Paerl, H.W., Pinckney, J.L., Steppe, T.F. 2000. Cyanobacterialbacterial mat consortia: examining the functional unit of microbial survival and growth in extreme environments. Environmental Microbiology 2(1): 11-26.

Penesyan, A., Kjelleberg, S., Egan, S. 2010. Development of Novel Drugs from Marine Surface Associated Microorganisms. Marine Drugs 8(3): 438-459.

Pina-Pérez, M.C., Rivas, A., Martínez, A., Rodrigo, D. 2017. Antimicrobial potential of macro and microalgae against pathogenic and spoilage microorganisms in food. Food Chemistry 235: 34-44.

Pratt, R., Daniels, T.C., Eiler, J.J., Gunnison, J.B., Kumler, W.D., Oneto, J.F., Strait, L.A., Spoehr, H.A., Hardin, G.J., Milner, H.W., Smith, J.H. 1944. Chlorellin, an antibacterial substance from Chlorella. Science 99: 351-352.

Quinn, R.J., Carroll, A.R., Pham, N.B., Baron, P., Palframan, M.E., Suraweera, L., Pierens, G.K., Muresan, S. 2008. Developing a drug-like natural products library. Journal of Natural Products 71(3): 464-468.

Rodríguez-Meizoso, I., Jaime, L., Santoyo, S., Señoráns, F.J., Cifuentes, A., Ibáñez, E. 2010. Subcritical water extraction and characterization of bioactive compounds from Haematococcus pluvialis microalga. Journal of Pharmaceutical and Biomedical Analysis 51: 456-463.

Santoyo, S., Rodríguez-Meizoso, I., Cifuentes, A., Jaime, L., GarcíaBlairsy Reina, G., Señorans, F.J., Ibáñez, E. 2009. Green processes based on the extraction with pressurized fluids to obtain potent antimicrobials from Haematococcus pluvialis microalgae. LWT - Food Science and Technology 42: 1213-1218.

Schlitzer, R. 2010. Ocean Data View Version 4.3.6. Bremerhaven: Alfred Wegener Institute. Available online at: http://odv. awi.de

Sengupta, S., Banerjee, A., Halder, U., Gupta, P., Banerjee, C., Bandopadhyay, R. 2019. Comparative study on structure of exopolysaccharide and capsular polysaccharide produced by Southern ocean origin Pseudoalteromonas sp. MB-16. Proceedings of the National Academy of Sciences, India Section B: Biological Sciences 89(1): 283290.

Sivak, E., Bugaev, S., Sokolov, M., Glinushkin, A. 2018. Antimicrobial Bio-Components from Red Algae Species: A Review of Application and Health Benefits. Entomology and Applied Science Letters 5(3): 85-90.

Syed, S., Arasu, A., Ponnuswamy, I. 2015. The uses of Chlorella vulgaris as antimicrobial agent and as a diet: the presence of bio-active compounds which caters the vitamins, minerals in general. International Journal of Bio-Science and Bio-Technology 7(1): 185-190.

Tanwar, J., Das, S., Fatima, Z., Hameed, S. 2014. Multidrug resistance: an emerging crisis. Interdisciplinary perspectives on infectious diseases 2014: 2014.

Tayler, E., Gregory, R., Bloom, G., Salama, P., Balkhy, H. 2019 Universal health coverage: an opportunity to address antimicrobial resistance? The Lancet Global Health 7(11): e1480-1.

Ventola, C.L. 2015. The antibiotic resistance crisis: Part 1: causes and threats. Pharmacy and Therapeutics 40(4): 277.

Wang, R., Chen, P., Jia, F., Tang, J., Ma, F. 2012. Optimization of 
polysaccharides from Panax japonicus CA Meyer by RSM and its anti-oxidant activity. International Journal of Biological Macromolecules 50(2): 331-336.

You, Q.H., Yin, X.L., Zhang, S.N., Jiang, Z.H. 2014. Extraction, purification, and antioxidant activities of polysaccharides from Tricholoma mongolicum Imai. Carbohydrate Polymer 99: 1-10.

Zhang, K., Sun, B., She, X., Zhao, F., Cao, Y., Ren, D., Lu, J. 2014.
Lipid production and composition of fatty acids in Chlorella vulgaris cultured using different methods: photoautotrophic, heterotrophic, and pure and mixed conditions. Annals of Microbiology 64(3): 1239-1246.

Zhang, Y.X., Dai, L., Kong, X.W., Chen, L.W. 2012. Characterization and in vitro antioxidant activities of polysaccharides from Pleurotus ostreatus. International Journal of Biological Macromolecules 51(3): 259-265.

Received: 08.06.2020

Accepted: 17.11 .2020 